\title{
NÖVÉNYVÉDELMI FÚVÓKÁK CSEPPMÉRETÉNEK ELEMZÉSE
}

\section{DROPLET SIZE ANALYSIS OF SPRAY NOZZLES}

\author{
Pásztor Judit, ${ }^{1}$ Kakucs András, ${ }^{2}$ Timár Zoltán, ${ }^{3}$ Egyed-Faluvégi Erzsébet ${ }^{4}$ \\ Sapientia EMTE, Marosvásárhelyi Kar, Gépészmérnöki Tanszék, Marosvásárhely, Románia \\ ${ }^{1}$ pjudit@ms.sapientia.ro \\ ${ }^{2}$ kakucs2@ms.sapientia.ro \\ 3 timar.zoltan@yahoo.com \\ ${ }^{4}$ faluvegi.erzsebet@ms.sapientia.ro
}

\begin{abstract}
In this paper we present laboratory equipment illustrating the operation of spraying nozzles, which is suitable for studying the basic processes of spraying and for measuring and evaluating the methods used in the control of sprayers. The equipment allows the monitoring of the spray film formed by the nozzles, measuring the yield of the nozzle and determining the size of the droplets formed. In the dissertation we explore the factors influencing the droplet size. We compare the average droplet diameter of the droplets formed by the three hydraulic principle nozzles. Based on the average droplet diameters, the operation of the spray nozzles is analyzed and conclusions are drawn.
\end{abstract}

Keywords: plant protection, nozzles, droplet size, water-sensitive paper.

\section{Összefoglalás}

Jelen dolgozatban egy növényvédelmi szórófúvókák működését szemléltető laboratóriumi berendezést mutatunk be, amely alkalmas a permetezés alapvető folyamatainak tanulmányozására, illetve a permetezőgépek ellenőrzésénél alkalmazott mérési, értékelési módszerek szemléltetésére. A berendezés lehetővé teszi a fúvókák által létrehozott permethártya megfigyelését, a fúvóka hozamának mérését, valamint a keletkezett cseppek méretének a meghatározását. A cikkben feltárjuk a cseppméretet befolyásoló tényezőket. Három, különböző hidraulikus elven működő fúvóka által képzett cseppek közepes cseppátmérőjét hasonítjuk össze. A cseppek közepes átmérőinek alapján a szórófúvókák működését elemezzük és következtetéseket vonunk le.

Kulcsszavak: permetezés, szórófúvóka, cseppméret, vízérzékeny papír.

\section{Bevezetés}

A növényvédelmi szórófúvókák a permetlé cseppekre való bontását valósítják meg.

A cseppek átlagos átmérője alapján megkülönböztetnek: permetezést, a cseppek mérete 80\%ban 150-750 $\mu$ m közötti; porlasztást, a cseppek 80\%-a 50-150 $\mu \mathrm{m}$ közötti; ködképzést, a cseppek 80\%-a 0,5-50 $\mu$ m közötti. [1]
A cseppképzés történhet hidraulikusan, pneumatikusan, mechanikusan, illetve termikusan [1].

A permetezőgépek általában hidraulikusan képzett cseppeket juttatnak a növényzetre. A cseppek képzése szórófúvókák segítségével történik. Egy szórófúvóka felépítése a következő (1. ábra): 1 szűrő; 2 - tömítés; 3 - szórófúvóka; 4 - bajonettzár; 5 - utáncsepegés-gátló. 


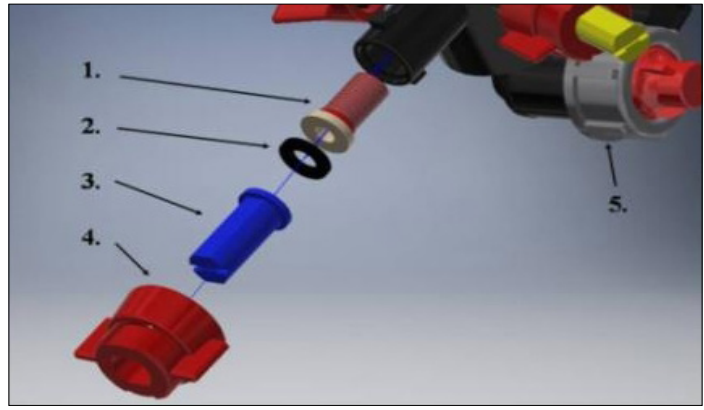

1. ábra. A szórófej felépítése

\subsection{A hidraulikus cseppképzés elméleti háttere}

A hidraulikus cseppképzés során a permetlé cseppekre bontása a szórófúvóka nyílásán nyomás alatt átáramló folyadékra ható erők hatására történik. A hidraulikus cseppképzés cirkulációval, örvényléssel vagy ütközéssel történhet.

Az örvényléssel képződő cseppek kör keresztmetszetű fúvókanyíláson keresztül haladva üreges kúphártyát képeznek (2. ábra).

Az ütközéssel képződő cseppek a folyadék szilárd felülettel, illetve folyadék folyadékkal való ütközése során, egy nyíláson keresztül haladva sík, legyezőszerü hártyát képeznek. Ezeket a fúvókákat használják a leggyakrabban. Réses fúvókáknak is nevezik őket (2. ábra).

\subsection{1. Áramlástechnikai összefüggések}

A hidraulikus cseppképzésű szórófúvókák által képzett cseppek közepes átmérőjének összefüggése:

$$
d_{\text {csepp }}=\frac{8 \cdot \sigma_{f}}{\rho_{\text {leveg } \sigma} \cdot v^{2} \cdot \alpha_{k}} \quad[\mathrm{~m}]
$$

ahol: $\sigma_{f}-$ a permetlé felületi feszültsége, [N/m],

$\rho_{\text {levegöó }}-$ a levegő sürüsége, $\left[\mathrm{kg} / \mathrm{m}^{3}\right]$;

$v-$ a folyadék kilépési sebessége, $[\mathrm{m} / \mathrm{s}]$;

$\alpha_{k}-$ a légellenállási együttható.

A cseppképzőből kilépő folyadékáram sebessége

$$
v=\mu \cdot \sqrt{\frac{2 \cdot \Delta p}{\rho_{\text {permetl é }}}\left[\frac{m}{s}\right],}
$$

ahol: $\mu$-szűkítési tényező,[-],

$\Delta p$ - a cseppképző nyomáskülönbség, [Pa];

$\rho_{\text {permetlé }}-$ a permetlé sűrüsége, $\left[\mathrm{kg} / \mathrm{m}^{3}\right]$.

A szúkítési tényező a fúvókán kilépő folyadéksugár átmérője és a fúvóka kilépési átmérőjének aránya:

$$
\mu=\frac{d_{\text {sugár }}}{d}[-],
$$

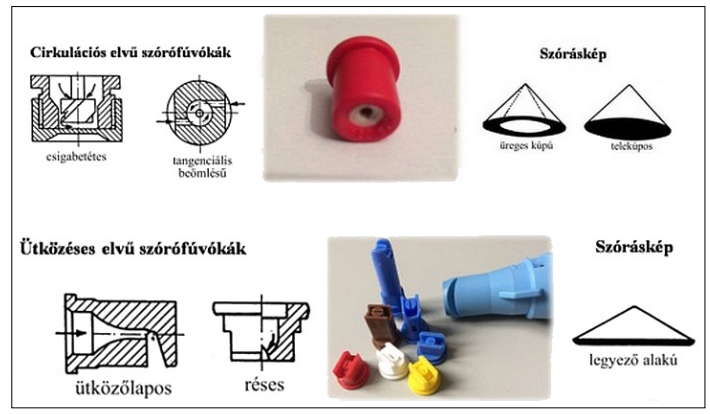

2. ábra. Hidraulikus cseppképzésü szórófúvókák felépítése, nyílása, szórásképe [1]

ahol: $d_{\text {sugár }}$ a fúvókán kilépő folyadéksugár átmérője, [m] és $d$ a fúvóka kilépési átmérője, [m].

Összegezve az (1), (2) és (3) összefüggéseket:

$$
\begin{aligned}
& d_{\text {csepp }}=\frac{8 \cdot \sigma_{f}}{\rho_{\text {leveg õ }} \cdot\left(\mu \cdot \sqrt{\frac{2 \cdot \Delta p}{\rho_{\text {permetl é }}}}\right)^{2} \cdot \alpha_{k}}[\mathrm{~m}], \\
& d_{\text {csepp }}=\frac{4 \cdot \sigma_{f} \cdot \rho_{\text {permetl é }} \cdot d^{2}}{\rho_{\text {leveg o o }} \cdot d_{\text {sugár }}^{2} \cdot \Delta p \cdot \alpha_{k}}[\mathrm{~m}] .
\end{aligned}
$$

$\mathrm{Az}$ (5) összefüggés feltárja a hidraulikusan képzett cseppek közepes cseppátmérőjét befolyásoló fizikai mennyiségek közti kapcsolatot. A közepes cseppátmérőt befolyásolja a permetlé felületi feszültsége, a cseppképző nyomáskülönbség, a permetlé sűrűsége, a fúvóka kilépési átmérője, nyílása.

A cseppképzés történhet kis nyomáson, 5 bar-értékig, közepes nyomáson, 5-15 bar között, és nagy nyomáson, 15 bar fölött [1].

Cél a cseppátmérő csökkentése, ugyanis adott térfogatú permetlével nagyobb felület fedhető be. A befedhető felület összefüggése:

$$
A=1,5 \cdot V_{f} \cdot \beta^{2} \cdot d_{c s e p p}^{-1}\left[m^{2}\right]
$$

ahol $V_{f}$ a folyadékmennyiség, [m³], $\beta$ pedig a szétterülési tényező (adimenzionális).

Az apró cseppek könnyen elsodródnak, ami veszteséget és fokozott környezetterhelést jelent. Ennek kiküszöbölésére terjedtek el a réses légbeszívásos szórófúvókák és a kompakt réses légbeszívásos szórófúvókák, amelyek légzárványokat hoznak létre az áramló permetlében. A légzárványos permetlé nagyobb cseppekre bontva érkezhet a növény felületére, ott a légköri nyomás hatására szétrobban, és jó fedést biztosít (3. ábra). A nagy cseppek érdekében a réses fúvókák kilépő nyílásainak mérete nagyobb, mint az azonos jelzésű standard fúvókáké. 


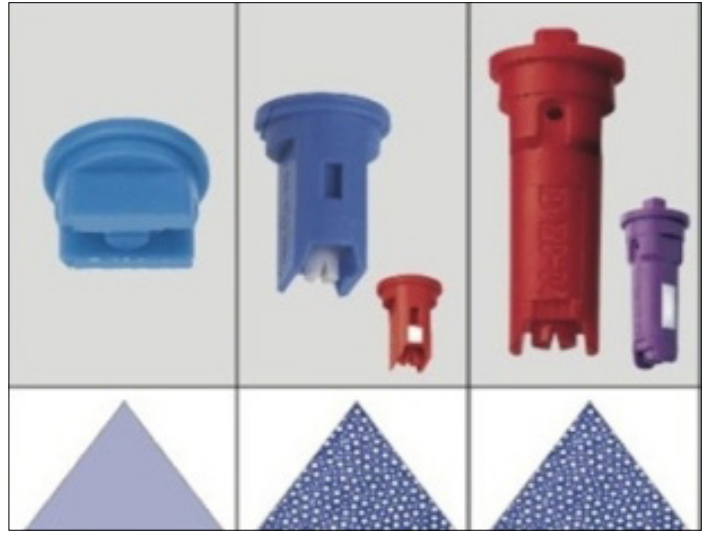

3. ábra. Réses standard és légbeszívásos fúvókák szórásképe

\section{A cseppméret vizsgálata}

Dolgozatunkban a hidraulikus elvü, réses szórófúvókák által képzett cseppek méretét kívánjuk tanulmányozni.

A cseppméret meghatározása történhet:

- kamerával;

- vízérzékeny papír segítségével.

A kamerával való cseppmeghatározás igen költséges, ezért vízérzékeny papír segítségével elemezzük, tanulmányozzuk a réses fúvókák cseppméretét.

A vízérzékeny papír 26x76 mm² felületű merev papír, amely sárga színü speciális bevonattal van ellátva. Vízzel érintkezve kékre színeződik. Ezt a módszert terepen való használatra fejlesztették ki. A papírt kihelyezik a permetezendő területre, majd permetezés után a megszáradt papírt összeszedik. Az eredmények kiértékelése történhet:

- referenciamintákkal való összehasonlítással;

- cseppek nagyító segítségével való számolásával, mérésével;

-számítógépes képfeldolgozással [2].

A vízérzékeny papír alkalmas a permeteloszlás, a cseppek sűrűségének és méretének ellenőrzésére [3].

\subsection{Kísérleti berendezés}

Létrehoztunk egy laboratóriumi berendezést, melynek segítségével a permetezést szimuláltuk. A berendezés lehetővé teszi a hidraulikus elvű, ütközéses cseppképzés megfigyelését. A növényvédelem alapvető folyamatainak a tanulmányozása érdekében a berendezésen nyomásmérés, hozammérés történik. A cseppképző nyomást egy centrifugál-szivattyú hozza létre. A berendezés részei a következők: 1 - tartály; 2 - csővezeték;

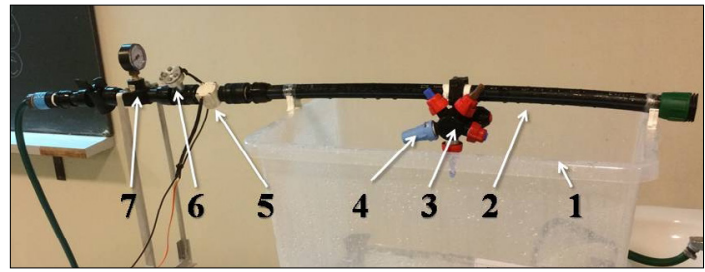

4. ábra. Kísérleti berendezés

3 - szórófej, benne a 4 - szórófúvóka. A felszerelt szórófej négy fúvóka fogadására alkalmas. A berendezés átfolyásmérő szenzorral (5), nyomásmérő szenzorral (6) és analóg nyomásmérővel (7) van felszerelve. A víz elvezetését lefolyóval oldottuk meg (4. ábra).

$\mathrm{Az}$ adatok gyüjtése Arduino Mega 2560 típusú mikrovezérlővel történik.

\subsection{A vizsgálat módszere, menete}

A dolgozatban laboratóriumi körülmények között történő cseppképzést vizsgáltunk, vízérzékeny papíron megjelenő vízfolt méretének meghatározása alapján.

A cseppképzést egy kisebb és egy nagyobb cseppképző nyomás esetén vizsgáltuk. Mérésenként 8 nyomás-adatot rögzítettünk, átlagot számoltunk. Az eredményeket a 7-9. ábrákon és az 1-2. táblázatokban tüntettük fel.

A vizsgálatot három szórófúvókán végeztük (5. ábra):

- Lechler SC-110-03 standard fúvókán;

- Lechler IDK-120-03 kompakt légbeszívásos fúvókán;

- Lechler ID-120-03 légbeszívásos fúvókán.

A 03-as számcsoport a keletkező csepp méretére enged következtetni, amelyet a fúvókák szabványos kék színével tesznek szemléletessé.

A laboratóriumi permetezés során a szórófejet manuálisan mozgattuk a vízérzékeny papír fölött 50 centiméter magasságban, mivel ilyen magasságban történik valós üzemeltetés közben is a permetezés [4]. A mozgatást gyorsan végeztük, annak érdekében, hogy kevés csepp ülepedjen le a papírra. A vízérzékeny papírt mindig a szórófúvóka permethártyájának függőleges szimmetriatengelyébe helyeztük, a tengelyre merőlegesen.

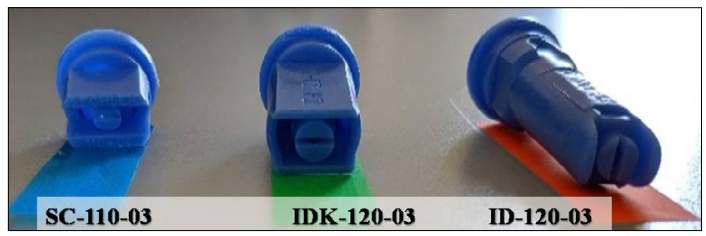

5. ábra. A vizsgált szórófúvókák 
A vízérzékeny papírlapok alá nedvszívó papírt helyeztünk, azért, hogy a szilárd felületről visszapattanó cseppek ne befolyásolják a mérés pontosságát (6. ábra).

A permetezéssel kezelt papírokat száradás után kemény alapra ragasztottuk, a szerszámmikroszkóppal való mérések elvégzése érdekében (7. ábra).

\subsection{Adatok gyüjtése és feldolgozása}

Szerszámmikroszkóp segítségével minden lapon összesen 10 darab vízfolt méretét határoztuk meg. A méréseket egy Carl Zeiss gyártmányú szerszámmikroszkóppal végeztük.

Azokat a foltokat mértük, amelyek szabályos kör alakot mutattak és rendelkeztek egy sötétebb, határozott körvonallal. A többi folt feltehetően több csepp egyesüléséből jött létre, és a vizsgálat szempontjából nem fontos a méretük meghatározása. A körvonal fontos a szerszámmikroszkóp szálkeresztjének pontos elhelyezésében (8. ábra).

A mérésre kiválasztott foltok körvonalán három helyzetet határoztunk meg. A három ponthelyzetből AUTOCAD program segítségével a $d_{\text {folt }}$ átmérőt számoltuk ki.

A foltméret segítségével cseppátmérőt számoltunk. A cseppátmérő meghatározásánál figyelembe vettük, hogy a cseppek a felületen szétterjednek, így az elemzéshez szükséges a $\beta$ szétterülési tényező. A szétterülési tényező a foltméret és a cseppek mérete, $d$ csepp közötti különbség korrigálására alkalmas. A gyártó foltméret-intervallumokhoz állapít meg szétterülési tényezőt. A vízpermet szétterülési tényezőjének értékei, $20{ }^{\circ} \mathrm{C}$-on, $40 \%$ relatív páratartalom, és ülepedési sebesség mellett az alábbi regressziós összefüggéshez vezetnek [3]:

$$
\beta=0,000857 \cdot d_{\text {folt }}+1,633333
$$

A cseppméret meghatározásának összefüggése:

$$
d_{\text {csepp }}=\frac{d_{\text {folt }}}{\beta}[\mathrm{mm}] \text {. }
$$

A mért és számolt adatokat az 1. táblázatba gyüjtöttük.

Az eredményeket összevetettük a gyártó által megadott adatokkal. A szavatolt cseppméretet a vizsgált szórófúvókák esetében a 2. táblázat tartalmazza.

Végül az adatokat megjelenítettük (9. ábra).

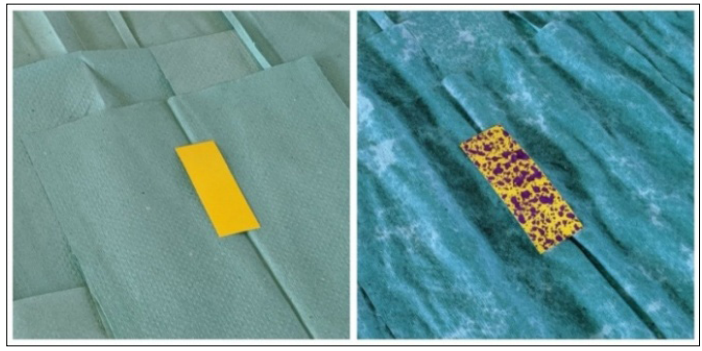

6. ábra. Vízérzékeny papír kezelés előtt és után

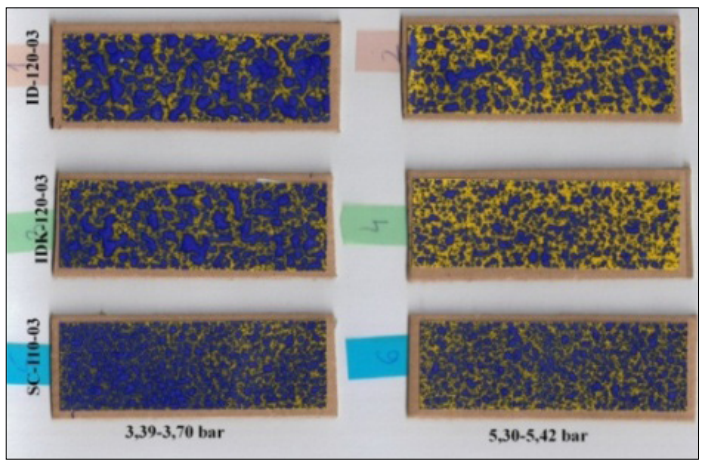

7. ábra. Permetezéssel kezelt vízérzékeny papírok
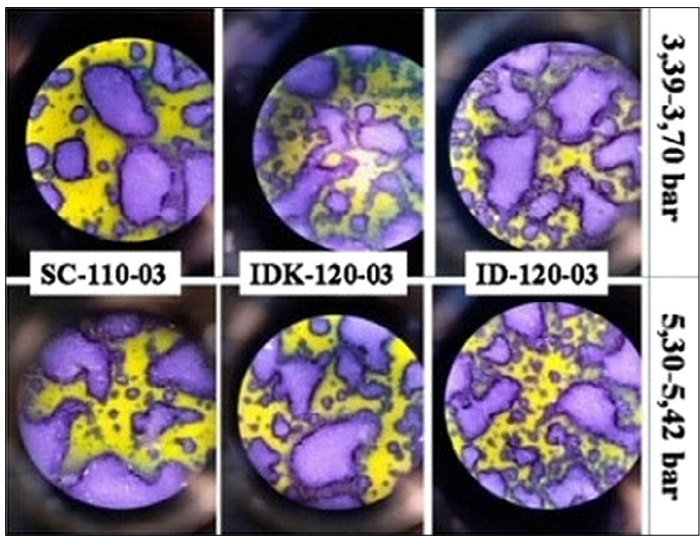

8. ábra. Foltméretek meghatározása

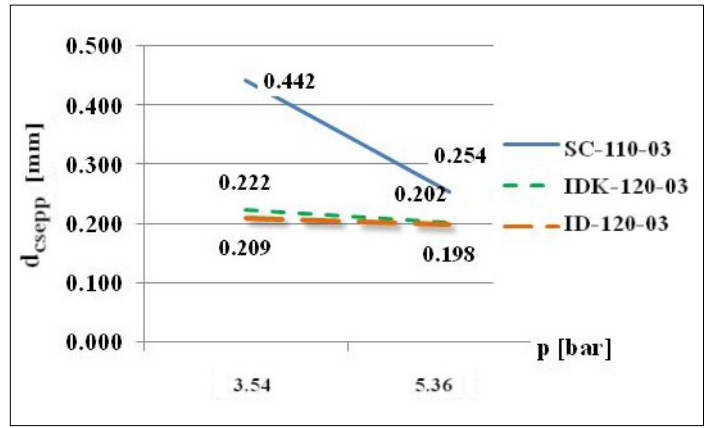

9. ábra. Kísérlet során a vízérzékeny papíron felfogott cseppek mérete 
1. táblázat. Mért és számolt adatok

\begin{tabular}{|c|c|c|c|c|c|c|c|c|c|c|c|c|}
\hline & \multicolumn{4}{|c|}{ SC-110-03 } & \multicolumn{4}{|c|}{ IDK-120-03 } & \multicolumn{4}{|c|}{ ID-120-03 } \\
\hline \multirow{2}{*}{\begin{tabular}{|l|l|l}
$\mathrm{p}$ bar $]$ \\
$d[\mathrm{~mm}]$
\end{tabular}} & \multicolumn{2}{|c|}{3.39} & \multicolumn{2}{|c|}{5.3} & \multicolumn{2}{|c|}{3.77} & \multicolumn{2}{|c|}{5.42} & \multicolumn{2}{|c|}{3.66} & \multicolumn{2}{|c|}{5.37} \\
\hline & dfolt & dcsepp & dfolt & dcsepp & dfolt & dcsepp & dffolt & dcsepp & dfolt & dcsepp & dfolt & dcsepp \\
\hline 1 & 0.274 & 0.168 & 0.410 & 0.251 & 0.447 & 0.274 & 0.280 & 0.171 & 0.465 & 0.284 & 0.353 & 0.216 \\
\hline 2 & 0.411 & 0.252 & 0.574 & 0.351 & 0.354 & 0.217 & 0.397 & 0.243 & 0.262 & 0.160 & 0.248 & 0.152 \\
\hline 3 & 0.341 & 0.209 & 0.534 & 0.327 & 0.282 & 0.173 & 0.410 & 0.251 & 0.284 & 0.174 & 0.317 & 0.194 \\
\hline 4 & 0.722 & 0.442 & 0.516 & 0.316 & 0.335 & 0.205 & 0.362 & 0.222 & 0.337 & 0.206 & 0.332 & 0.203 \\
\hline 5 & 0.647 & 0.396 & 0.400 & 0.245 & 0.458 & 0.280 & 0.295 & 0.180 & 0.324 & 0.199 & 0.329 & 0.201 \\
\hline 6 & 0.943 & 0.577 & 0.429 & 0.262 & 0.408 & 0.250 & 0.334 & 205 & 0.323 & 0.197 & 0.359 & 220 \\
\hline 7 & 0. & 0.205 & 0.234 & 13 & 0. & 8 & 44 & 10 & 0.308 & 88 & 0.331 & 02 \\
\hline 8 & 0.319 & 0. & 0.384 & 0.235 & 0.363 & 0.222 & 0.238 & 0.146 & 0.303 & 0.185 & 0.284 & 0.174 \\
\hline 9 & 1.104 & 0.675 & 0.276 & 0.169 & 0.302 & 0.185 & 0.342 & 0.209 & 0.535 & 0.328 & 0.332 & 0.203 \\
\hline 10 & 2.123 & 1.299 & 0.388 & 0.238 & 0.357 & 0.219 & 0.298 & 0.182 & 0.267 & 0.163 & 0.344 & 0.211 \\
\hline & lag [mm] & 0.442 & & 0.254 & & 0.222 & & 0.202 & & 0.209 & & 0.198 \\
\hline szórás & $\mathrm{s}$ [mm] & 0.121 & & 0.004 & & 0.001 & & 0.001 & & 0.003 & & 0.000 \\
\hline
\end{tabular}

2. táblázat. A gyártó által szavatolt cseppméretek [5], [6]

\begin{tabular}{|c|c|c|l|}
\hline $\mathbf{p}$ [bar] & \multicolumn{3}{|c|}{$\mathbf{d}_{\text {csepp }}$ [mm] } \\
\hline & SC-110-03 & IDK-120-03 & ID-120-03 \\
\hline $3,39-3,70$ & $0,200-0,250$ & $0,400-0,450$ & $0,500-0,550$ \\
\hline $5,30-5,42$ & $0,190-0,200$ & $0,300-0,350$ & $0,450-0,500$ \\
\hline
\end{tabular}

\section{Következtetések}

A cseppképzés nagyon összetett folyamat.

A cseppképzés elmélete alapján a kisebb kilépő nyílás mellett apróbb cseppek képződnek. A megfigyelésünk esetében ez nem igazolódott. Az SC110-03 típusú standard réses fúvóka, a legkisebb nyílással rendelkező fúvóka által kezelt vízérzékeny papíron határoztuk meg a legnagyobb cseppméretet. Ez azzal magyarázható, hogy a gyártó ezt a fúvókát 2 bar alatti nyomásra javasolja. Valószínűsíthető, hogy a nagyobb nyomáson keletkezett igen kisméretű cseppek az ülepedés során egyesültek, így alkothattak nagyobb méretű foltokat.

A cseppméret alakulása a nyomás függvényében mindhárom fúvóka esetében igazolódott, nagyobb nyomáson kisebb mérető cseppek keletkeznek.

Az IDK-110-03 és ID-110-03 fúvóka közel azonos méretü cseppeket hozott létre. Ezek a cseppméretek kisebbek, mint a gyártó által szavatoltak. A jelenség azzal is magyarázható, hogy az általunk mért cseppek az utólagos csepprobbanás eredményei.

A kísérlet magyarázza a szakirodalomban leírt és ismertetett folyamatokat, azonban nem szem- lélteti a légzárványokat, csak következtetni lehet a jelenlétükre.

A megvalósított berendezés alkalmas a permetezés laboratóriumi körülmények közötti megfigyelésére, a fúvókatípus és cseppméretek közötti öszszefüggések tanulmányozására, a permethártya megfigyelésére, azonban a cseppméret meghatározása a vízérzékeny papír és mikroszkóp segítségével pontatlansághoz vezethet.

A mérési módszer pontosabbá tétele érdekében további kutatást javasolunk.

\section{Szakirodalmi hivatkozások}

[1] Láng Z.: A zöldség-, dísznövény- és szaporítóanyag-termesztés berendezései és gépei. Mezőgazda Kiadó, Budapest, 1999. 142-155.

[2] Hoffmann W. C., Hewitt A. J.: Comparison of Three Imaging Systems for Water-Sensitive Papers. Applied Engineering in Agriculture. American Society of Agricultural Engineers, ISSN 0883-8542. 21(6) 2005. 961-964.

https://www.researchgate.net/publication/43254997_Comparison_of_three_imaging_ systems_for_water-sensitive_papers

[3] Instructions for Water Sensitive Paper, 99500028, 2006.

http://www.frostserv.com/WSPinstructions.pdf (letöltve: 2019. november 15.).

[4] https://www.lechler.com/fileadmin/media/kataloge/pdfs/metallurgy/EN/lechler_brochure_rollcooling_en.pdf (letöltve: 2019. november 19.)

[5] Pályi B.: Permetezőgépek üzemi beállítása, ellenőrzése. Agrónapló, 2019/2.79-82.

https://www.agronaplo.hu/szakfolyoirat/2019/02/ gepesites/permetezogepek-uzemi-beallitasa-ellenorzese (letöltve: 2019. november 15.).

[6] https://www.awri.com.au/wp-content/uploads/2016/11/spray-application-workshop-liquid-flow.pdf (letöltve: 2019. november 19.) 